\title{
CONSTRUYENDO HECHOS: ANÁLISIS DE LAS METÁFORAS UTILIZADAS EN LA PRODUCCIÓN CIENTÍFICA CHILENA SOBRE APEGO E INFANCIA TEMPRANA
}

\author{
CONSTRUCTING FACTS: ANALYSIS OF THE METAPHORS USED \\ IN THE CHILEAN SCIENTIFIC PRODUCTION ON ATTACHMENT \\ AND EARLY CHILDHOOD
}

\author{
Claudia Calquín-Donoso* \\ Universidad de Santiago de Chile \\ Santiago-Chile \\ Rodrigo Guerra-Arrau \\ Universidad Diego Portales \\ Santiago-Chile \\ Sebastián Vásquez-Vásquez \\ Universidad Diego Portales \\ Santiago-Chile
Cristopher Yáñez-Urbina
Universidad Diego Portales
Santiago-Chile \\ Recibido mayo de 2020/Received May, 2020 \\ Aceptado noviembre de 2020/Accepted November, 2020
}

\begin{abstract}
RESUMEN
El artículo presenta los principales resultados de una investigación dirigida a conocer los significados de la infancia y su cuidado en la producción científica chilena respecto del apego. Para lograr este objetivo se realizó un análisis de metáforas en 19 artículos científicos pertinentes al apego publicados por investigadores chilenos durante el período 2010-2017 en revistas catalogadas en Web of Science, Scielo y Scopus. Las metáforas analizadas muestran los desplazamientos de significados culturales a la investigación científica y los modos en cómo los léxicos naturalísticos, empresariales, computacionales, bélicos, entre otros, modelan los modos de conceptualizar la infancia y la relación madre-hijo.
\end{abstract}

Palabras Claves: Apego, Metáforas, Infancia, Maternidad.

\section{ABSTRACT}

The article presents the results of an analysis aimed at understanding the meanings of childhood and its care in the Chilean scientific production on attachment. To achieve this aim, a metaphor analysis was performed on 19 scientific articles on attachment published by Chilean researchers during the period 2010-2017 in journals cataloged in Web of Science, Scielo and Scopus. The 
metaphors analyzed show the displacements of cultural meanings in scientific research and the ways in which naturalistic, business, computer, warlike lexicons, among others, model the ways of conceptualizing childhood and the mother-child relationship. Key Words: Attachment, Metaphor, Childhood, Motherhood.

\section{INTRODUCCIÓN}

La teoría el apego, así como sus derivas contemporáneas (Bowlby, 1969; 1972; Hulbert, Jennings, Jackson, y Chanen, 2011; Lecalennier, 2006; Lorenzini, y Fonagy, 2014), se han posicionado de forma creciente en la psicología infantil como un modelo explicativo hegemónico del desarrollo psicológico de niñas y niños, y un referente técnico central en las políticas públicas dirigidas a la infancia temprana. Esta doble matriz de significados erige al apego como un concepto privilegiado para indagar en las articulaciones sociotécnicas en la conformación de objetos científicos, mostrando que su definición y circulación dependen de un conjunto de mediaciones culturales. Este trabajo indaga en el problema de conocimiento "psi" y sus formas particulares de interpretar el mundo de los niños/as revelando que las disciplinas no solo movilizan hechos, sino valores y universos sociosimbólicos. (Ramos, 2016).

Así planteado, se presentan los resultados de un análisis dirigido a indagar en las estrategias discursivas, en particular metafóricas, que se despliegan en los textos científicos sobre apego en el período 2010-2017 como una forma de atender a la trama de significaciones en las cuales es producido cierto saber sobre la infancia temprana. De modo puntual se realizó un análisis de metáforas (Pragglejaz Group, 2007; Lakoff \& Johnson, 1998) para responder a la pregunta acerca de ¿cuáles son las versiones acerca de la infancia y su cuidado que se construyen en la investigación chilena sobre apego e infancia temprana? Desde una perspectiva inspirada en los desarrollos de los estudios sociales de la ciencia y del teoría actor red (Callon, 1986, 1998; Callon \& Law, 1998; Domenech y Tirado, 1998; Latour, 2008) se revelará que el concepto de apego emerge como un tipo particular de objeto que, siguiendo a Trompette \& Vinck (2009), llamamos objeto frontera, el cual articula diversos dominios sociales, tales como la producción científica, sus redes de circulación, los imaginarios culturales, las políticas públicas, entre otros.

\section{El apego como objeto frontera}

En otro lugar (Calquín, 2016) hemos analizado la emergencia del apego en la teoría psicoanalítica como un fenómeno estrechamente vinculado a las transformaciones del género y la sexualidad que se aprecian una vez finalizada la segunda guerra mundial en los países de Europa y Norteamérica, y que se inscribió dentro de lo que ha sido llamado el giro hacia la madre en la teoría psicoanalítica. Sin ahondar en el trabajo realizado por el padre fundador, el psicoanalista inglés John Bowlby así como los importantes desplazamientos y giros que este investigador llevó a cabo al interior del psicoanálisis, la clave de la teoría del apego es que asigna una importancia central a los vínculos afectivos tempranos que se generan entre el bebé y la madre. Se establece que existe una motivación intrínseca en los seres humanos a generar lazos emocionales prolongados y consistentes, desde el nacimiento hasta la muerte, con la función principal de obtener cuidado, protección y estimulación en su desarrollo evolutivo por parte del cuidador primario (Bowlby, 1969).

La teoría del apego ha sufrido una serie de revisiones, incorporando conceptos y categorías del cognitivismo y la teoría sistémica, entre otros, en un programa de investigación que se orienta a: vincular ciertos tipos de configuraciones de apego a trastornos de la personalidad (Lorenzini y Fonagy, 2014; Hulbert et al., 2011), comprender las relaciones de apego con variables psicosociales como el maltrato y la pobreza (Fresno, Spencer, Leiva y Gallardo, 2011) y crear tecnologías de intervención y prevención en la infancia más temprana (Barudy y Dantangan, 2005). De esta forma podríamos hablar que actualmente existe un sistema o campo teórico en relación al apego (Lecalennier, 2006).

Por otra parte, el apego ha franqueado los límites de la academia y la práctica de la psicología como ciencia, para instalarse en diversos ámbitos de las políticas de infancia: la educación preescolar, la salud mental, entre otros campos y que de algún u otro modo retroalimentan y relegitiman este saber. En este juego de mutuas influencias y traducciones (Callon,1998) es posible pensar al apego como una entidad teórica, que existe gracias a una red de relaciones de elementos de naturaleza heterogénea y que, en sus relaciones, van produciendo un entramado discursivo que trasciende la misma práctica 
científica para anudarse con proyectos políticos y con las vidas cotidianas. Es a partir de esta red, que el apego se ha ido erigiendo como un conocimiento autorizado (Jordan, 1992) respecto a las formas de gestión de la vida emocional de los niños, y también, de sus madres. Hablamos, por lo tanto, de un conocimiento sobre el cual un grupo social dado, lleva a cabo procesos de toma de decisiones acerca de las maneras de regular las vidas de las familias, especialmente más vulnerables, grupo en donde el apego ha sido mayormente estudiado.

La variedad de contextos en los cuales se construye el objeto apego hace que sea plausible pensarlo como un objeto frontera (Star y Griesemer, 1989) que pone en escena el rol de toda clase de artefactos en su producción (Trompette y Vinck, 2009 , p. 1). El apego, como objeto frontera, circula entre la ciencia social, el estado, los grupos de interés, el mercado y la vida cotidiana. La noción de objeto frontera indica que el trabajo científico se mueve, por un lado, en una tensión entre múltiples "puntos de vistas" muchas veces divergentes y, por otro, por la necesidad de generalizar y consensuar sus hallazgos. El objeto frontera expresa la voluntad por superar las dicotomías clásicas que recubren los análisis de la ciencia: naturaleza-sociedad; ciencia-política, conocimiento experto-sentido común, llevando a cabo un desplazamiento en que los objetos de conocimiento se comprenden como nodos de una red "que no son más que conjunto de relaciones; o conjuntos de relaciones entre relaciones" (Domenech y Tirado, 1998, p. 24).

A partir de la definición de Star y Griesemer (1989) los objetos-frontera son flexibles a la interpretación, a la estructuración material y de organización de sus distintos tipos aplicándose a un espacio compartido en el que coinciden las fronteras de distintos saberes y acciones. Siguiendo a Goodman (1990), "es posible que entidades misceláneas pertenezcan a un mismo mundo cruzándose entre sí y formando, al hacerlo, complejos diseños...los mundos pueden ser diferentes sino todo lo que a uno de ellos pertenece también a otro" (p. 26). Por ejemplo, en estas relaciones, el apego sería posible de medir de forma válida y confiable por los investigadores $\mathrm{y}$, a la vez, permitiría a los gobiernos conocer los impactos de formas de vida y relación no hegemónicas o desviadas y proponer estrategias de tratamiento mediante políticas públicas e intervenciones profesionales. También, a las madres y profesionales, permitirían traducir el enigmático mundo psíquico infantil temprano. Así, el apego transita y es coproducido por instancias múltiples constituyendo a los objetos fronteras como "el centro de controversias entre actores de diferentes entornos que pugnan por definirlos" (Rodríguez, 2013, p. 15).

Si bien el apego ha cobrado mayor relevancia en la academia e instituciones altamente especializadas en la prevención, protección y reparación en temáticas de la infancia vulnerada en sus derechos, especialmente en Residencias de Protección, Programas de Familias de Acogida y Servicios de Adopción; también circula, es representado y resignificado por agentes no técnicos en ámbitos como la escuela, los jardines infantiles, los programas televisivos, etc. En Chile el apego se ha erigido en un objeto epistémico del Estado (Ramos, 2016) mediante el Sistema de Protección Integral a la Infancia "Chile Crece Contigo", cuyos destinatarios son los niños y niñas desde la gestación hasta los 4 años de edad (Chile Crece Contigo, 2008; Saavedra, 2015). El apego vincula entidades no académicas que se erigen como espacios de experticia de la infancia temprana por medio del estudio y promoción del apego (por ejemplo la Fundación América para la Infancia) y que modelan este objeto incompleto como si fuera un objeto unificado, natural, dado, estable, que es posible medir soslayando los problemas que los objetos psíquicos tienen para la práctica interpretativa dentro de la psicología científica (Teo, 2008), y que se ofrece al Estado para tomar ciertas decisiones de tipo normativas acerca del desarrollo adecuado de los niños y niñas. Asimismo, el apego es objetualidad, pues es parte de un universo de artefactos construidos para el mercado de la infancia así como se muestra en los kits de "Apego seguro" que van desde portabebés hasta aceites para masajes.

Apreciamos, por tanto, que la materialidad del apego proviene de la acción tanto de científicos, gestores de políticas públicas, profesionales, fabricantes de juguetes, madres, entre otros, y también entidades no humanas (kits, portabebés, etc.), es decir, voceros de distintas esferas que no son sociales ni naturales, ni estatales, ni mercantiles, sino que son híbridos (Haraway, 2011), que en su relación visibilizan y le dan forma como objeto epistémico. Una forma que permite dar respuesta a la incertidumbre y ambigüedad del proceso de demarcación entre el desarrollo infantil normal del "desviado", y en el trabajo de elaboración de diagnósticos de la 
infancia realizados en contextos múltiples, lo que permite la negociación continua de los significados de la infancia y su cuidado.

\section{Ciencia y Discurso: Las metáforas y la} investigación acerca de apego

Como señalamos en párrafos anteriores, el apego como objeto frontera revela que los contornos de la psicología como actividad científica son extremadamente fluidos y negociables y, en ese sentido, es que el análisis de las metáforas que estructuran los discursos y prácticas en torno a este objeto son una alternativa posible para examinar los modos en que la ciencia misma se produce, entre otras, por y en medio de tecnologías literarias y lingüísticas. En psicología, las metáforas adquieren atención con las teorías del construccionismo social y para el caso de la historia de la psicología son centrales los trabajos de Lakoff y Johnson (1998), así como los de Leary (1990) y Danziger (1990). Estos dos últimos autores identifican -especialmente con el auge del cognitivismo- varias metáforas tecnológicas basadas en la analogía con los computadores, los sistemas cibernéticos, el procesamiento de información, etc. Para Crespo (2003) las teorías incorporan metáforas existentes en la sociedad y, asimismo, son productoras de metáforas que son utilizadas por las personas para dar sentido a sus existencias. Como sugiere Haraway (2011), la práctica científica se hace posible por medio de construcciones retóricas que aportan "coherencia, sentido de totalidad y potencialidad persuasiva" (p. 137) a nuestras categorías con las que pensamos y actuamos en el mundo.

La construcción del discurso científico es una construcción social del habla, "un proceso social que se encuentra contextualizado" (Cabrera, et al., 2010, p. 205). Es por ello que la constitución de un saber científico respecto de la infancia no puede estar desligada del contexto discursivo y retórico donde este se produce. Si bien en nuestra cultura la ciencia tiene la función de resolver problemas y plantear una mirada acerca de la realidad que suele tomar distancia de lo que llamamos "sentido común" (Castro, 2015), es claro que un saber científico se constituye como tal en tanto es comunicable. Esta comunicación implica ciertas operaciones y procedimientos de apropiación, reformulación y traducción de categorías previas que disuelven los límites entre los lenguajes "científicos" y "no científicos", sobre todo cuando estos conocimientos se producen directa o indirectamente con el objetivo de transmitirlo en contextos distintos a los de su producción (Castro, 2015).

Esta potencia para vincular contextos múltiples se desprende de la cualidad asociativa de la metáfora. Para Lakoff y Johnson (1998), los conceptos metafóricos son asociaciones sistemáticas entre lo que llaman dominios múltiples: uno conocido, estructurado o manipulable, que ellos llaman Dominio de Origen (DO), y otro desconocido, no tan estructurado o no manipulable que correspondería al Dominio de Destino (DD). En esta relación, el DO proyecta al DD sus elementos constitutivos y lógicas internas, imponiendo determinadas condiciones a la estructura del DD y fijando las correspondencias entre los dos dominios. El ejemplo de estos autores es sencillo. Expresiones como "esas afirmaciones son indefendibles", "atacar los puntos débiles del argumento" o "las críticas dieron justo en el blanco" se derivan de la metáfora de: "una discusión es una guerra". En esta metáfora, el dominio de origen es "guerra", mientras el dominio destino es "discusión", ya que el primero le concede sentido y estructura al segundo, que hasta entonces permanece más indeterminado.

Así la metáfora establece un isomorfismo entre dos órdenes de experiencia y entidades diferentes (Millán y Narotsky, 1998). Por ejemplo Lakoff y Johnson (1998) argumentan que los tres tipos "naturales" de experiencia-corporal, ambiente físico y de la cultura- constituyen los dominios básicos en los que se levantan las metáforas. Esto nos permite abordar el apego como objeto frontera de una forma privilegiada, pues aquella nos lleva a la movilidad de las demarcaciones entre ciencia y cultura y a los modos en que los sentidos comunes y las imágenes afectivas (Autor) se introducen en el mismo proceso de producción de conocimientos racionales acerca de la relación madre-hijo, desplegando un entramado de juegos de verdad y acontecimientos discursivos de diverso orden, que permiten la constitución y emergencia de un saber autorizado y convincente.

Desde nuestra perspectiva, hay que puntualizar que los textos que refieren al mundo infantil precoz (un objeto de por sí resbaladizo y menos estructurado) el análisis también tiene que ver con el conjunto de selecciones léxicas y gramaticales que llevan a cabo los investigadores para operar procesos de "traducción" del enigmático mundo psíquico infantil temprano (desprovisto de habla). Siguiendo a Martínez (2014), la generación de lo 
que llama "metáforas inusitadas" nos permite establecer "conexiones y asociaciones alternativas entre significados hasta entonces desvinculados" (p. 9). Así dicho, las metáforas son una herramienta de indagación en esta permeabilidad entre ciencia y cultura que nos lleva a reconocer la matriz cultural que subyace y cruza a los estudios pertinentes a infancia y "crea un universo semántico abierto a la significación y a la vez presenta el objeto de forma descriptiva" (Amar, 2014, p. 235). Las metáforas permiten así conectar la ciencia con su exterioridad o aquello que permanece afuera, y representa una economía en la comunicación, pues describe con un mínimo de palabras un máximo de significados.

\section{MATERIAL Y MÉTODO}

Los resultados que se presentan son fruto de una investigación de carácter cualitativa y que se aproxima a los estudios del discurso, entendidos como un conjunto diverso de enfoques y prácticas analíticas que hace eco a diversas tradiciones dentro de la investigación cualitativa y que entiende al discurso como una práctica social y del lenguaje (Orlandi, 2012; Ibáñez, 2011; Íñiguez, 2006; Wodak, y Ferreiro, 2013). Esta perspectiva es un enfoque de análisis que orienta los diseños metodológicos, pero que no se basa en un conjunto de métodos o técnicas predefinidas o rígidas. Asimismo, desde el punto de vista del estudio de la infancia, la perspectiva discursiva es privilegiada para indagar y cuestionar la especificidad de las concepciones sociales que atraviesan la producción de la identidad infantil (Vergara et al., 2015).

De modo puntual, se trabajó con el análisis de metáforas (Lakoff y Johnson, 1998; Berri y Bregant, 2015; Shotter, 2001) entendidas estas como elementos analíticos transversales de la vida cotidiana, el pensamiento y la acción y también un recurso lingüístico que permite fabricar hechos (Potter, 1996; Haraway, 2011). Las metáforas abarcan todos los tropos o figuras literarias que nos permiten "comprender y experimentar una clase de cosas en términos de otra" (Lakoff y Johnson, 1998, p. 55) y que surgen por la necesidad de traducción de los conceptos que no están claramente delineados en nuestra experiencia por otros que "entendemos con mayor claridad" (p. 156). Las metáforas no son solo fenómenos estéticos sino que se trata sobre todo de fenómenos sociosimbólicos que involucran nuestra concepción del mundo y que contribuyen en la estructuración de cualquier tipo de discurso, desde un texto científico hasta una conversación casual (Meza, 2010).

Siguiendo a Atkinson y Coffey (2005), las funciones que tienen las metáforas para el Análisis del Discurso son:

1. Permiten al analista explorar los mecanismos lingüísticos empleados por los actores sociales y cómo revelan concepciones y significados compartidos.

2. Ayudan a identificar los terrenos culturales compartidos para los miembros de una cultura o subcultura dadas, es decir, identificar aquello que se da por establecido o como de sentido común.

3. Ayudan a identificar los mecanismos retóricos que le sirven al hablante para un propósito particular.

\section{Procedimiento}

En primer lugar se utilizó el Procedimiento para la Identificación de la Metáfora (MIP) (Pragglejaz Group, 2007) [Imagen 1] en el que se aplicó lo siguiente:

1. Determinó las unidades léxicas del texto -principalmente locuciones y modismos- luego de una lectura exhaustiva para comprender su significado general.

2. Identificó el significado contextual de cada unidad léxica, esto es, el significado que esta unidad tiene en la situación en la que se está usando. Para esto se recurrió tal como indica en el procedimiento al Diccionario de la Lengua Española (RAE, edición número 23) en versión online.

3. Verificó también por medio del diccionario si hay un significado más básico de esta unidad léxica e identificarlo. Este significado se caracteriza por ser más concreto, porque lo que evoca es más fácil de imaginar, ver, escuchar, sentir, oler y gustar, por estar relacionado con la acción corporal y por ser más específico.

4. Determinó si el significado más básico es lo suficientemente distinto del significado contextual.

5. Examinó si el significado contextual puede relacionarse con el básico mediante alguna forma de similitud.

Una vez identificadas las expresiones metafóricas, como se aprecia en la misma imagen 1 , se aplicó un segundo procedimiento propuesto por 


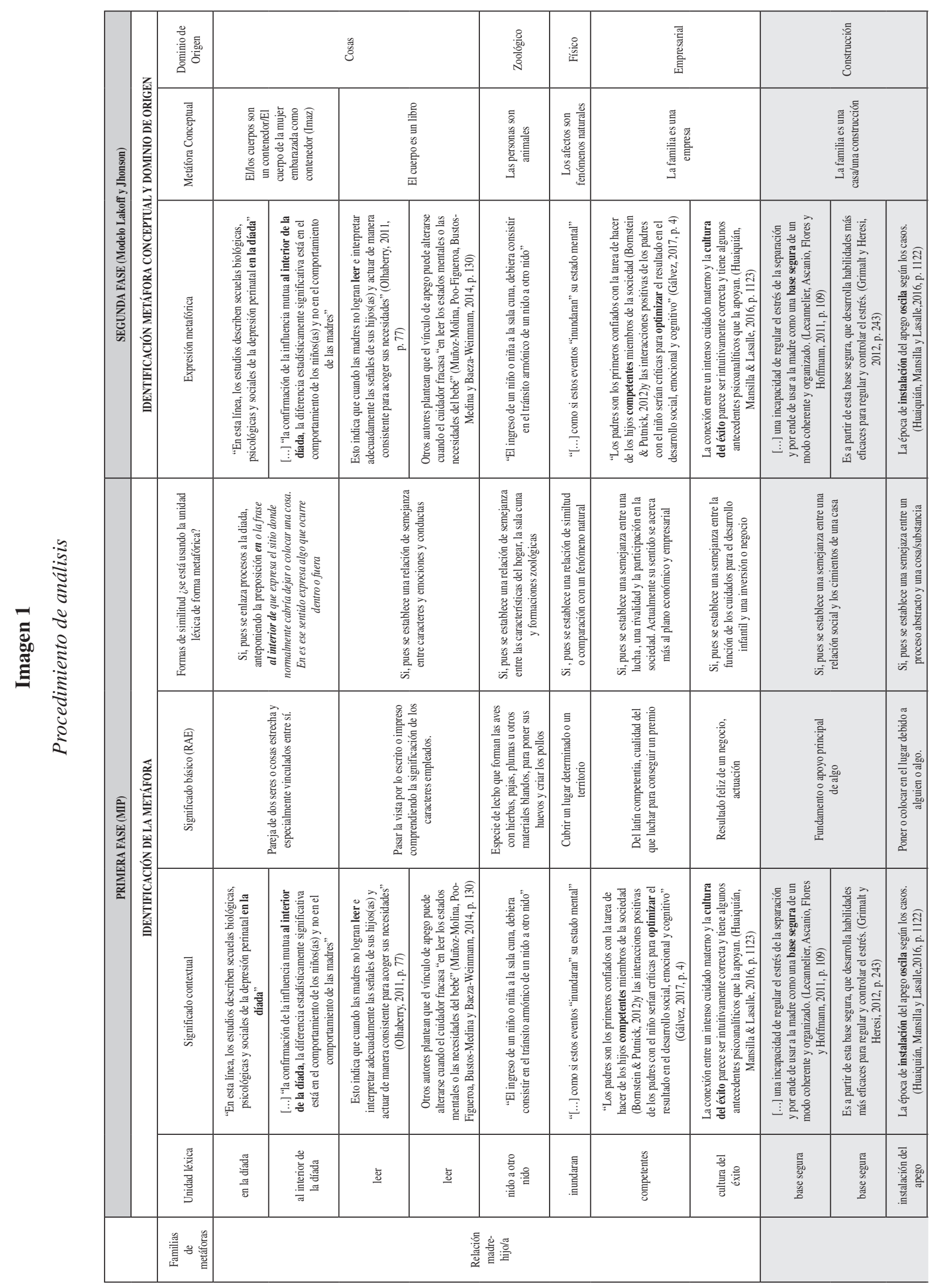




\begin{tabular}{|c|c|c|c|c|c|c|c|c|c|c|c|}
\hline \multicolumn{3}{|c|}{ 駕 } & \multicolumn{4}{|c|}{ 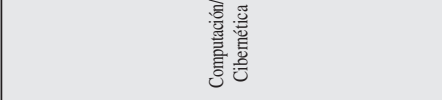 } & \multicolumn{2}{|r|}{ 㺃 } & 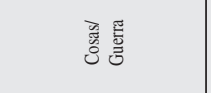 & \multicolumn{2}{|l|}{ 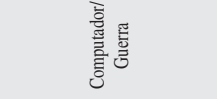 } \\
\hline \multicolumn{3}{|c|}{ 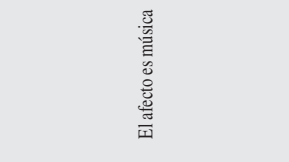 } & \multicolumn{4}{|c|}{ 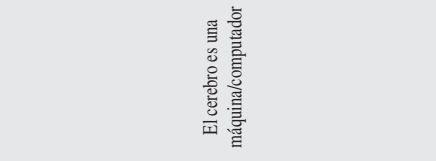 } & \multicolumn{2}{|c|}{ 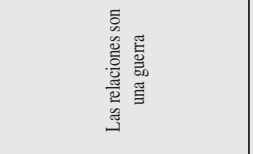 } & 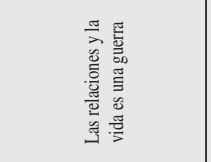 & \multicolumn{2}{|c|}{ 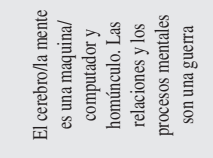 } \\
\hline 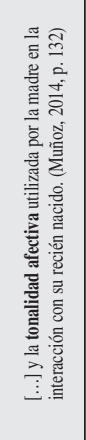 & 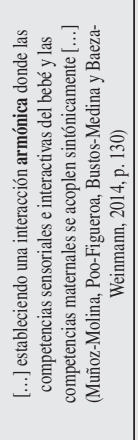 & 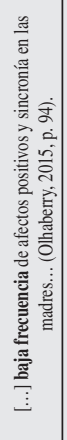 & 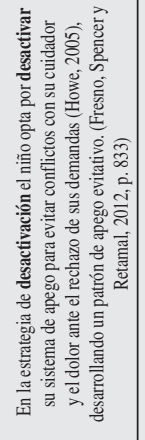 & 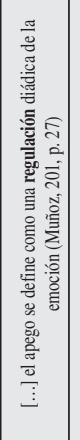 & 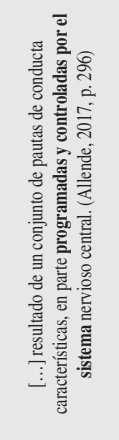 & 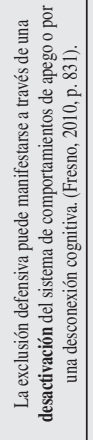 & 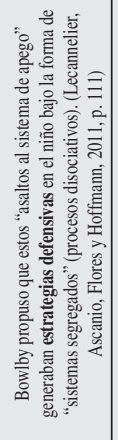 & 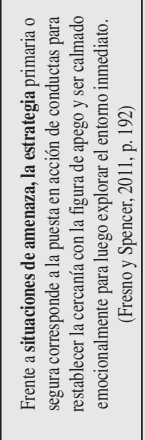 & 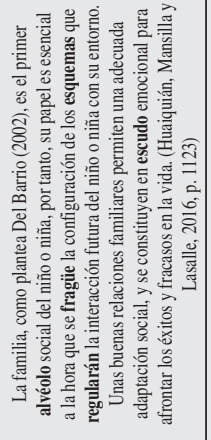 & 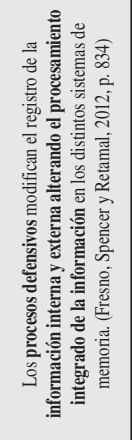 & 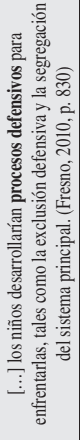 \\
\hline \multicolumn{3}{|c|}{ 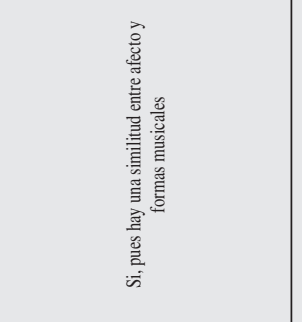 } & \multicolumn{4}{|c|}{ 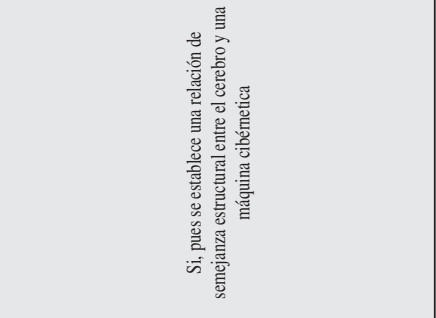 } & \multicolumn{2}{|c|}{ 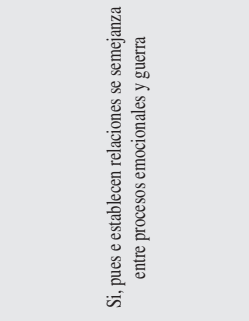 } & & \multicolumn{2}{|c|}{ 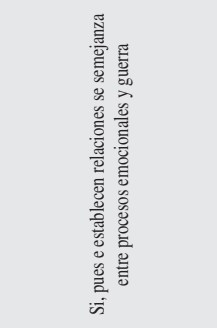 } \\
\hline 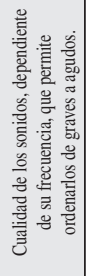 & 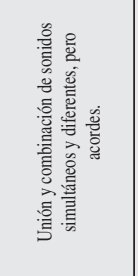 & 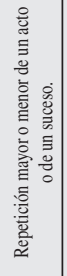 & 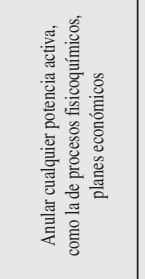 & 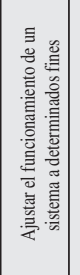 & 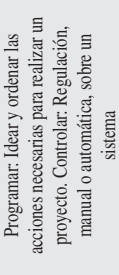 & 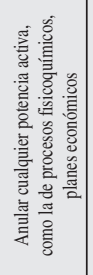 & \multicolumn{2}{|c|}{ 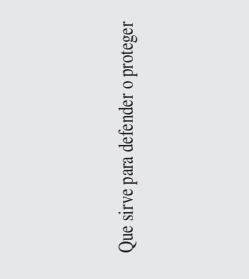 } & 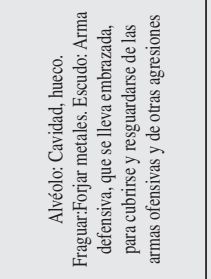 & \multicolumn{2}{|l|}{ 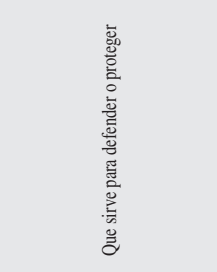 } \\
\hline 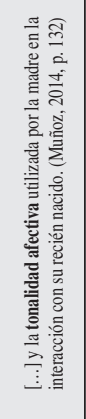 & 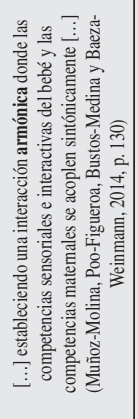 & 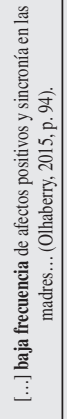 & 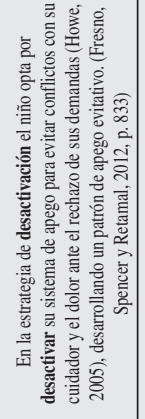 & 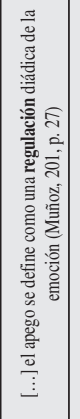 & 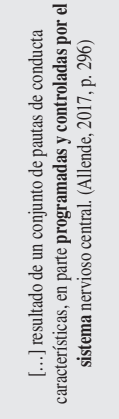 & 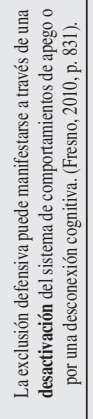 & 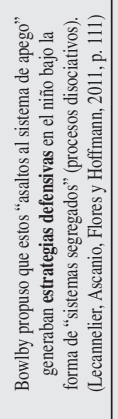 & 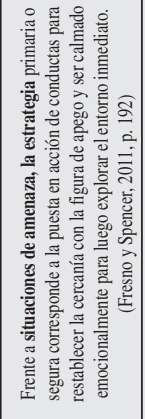 & 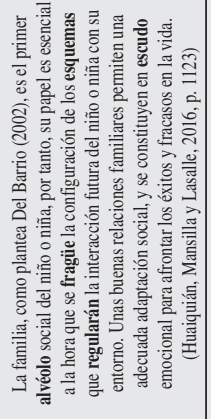 & 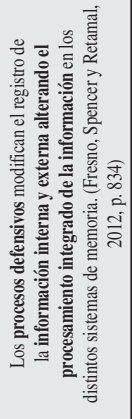 & 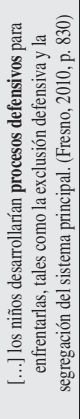 \\
\hline 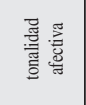 & $\begin{array}{l}\text { 莺 } \\
\text { 言 }\end{array}$ & $\mid$ & 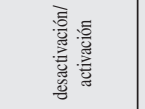 & 总 & 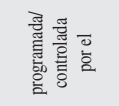 & 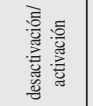 & 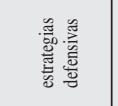 & 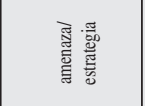 & 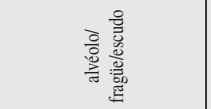 & 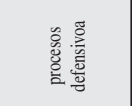 & 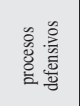 \\
\hline
\end{tabular}


Lakoff y Johnson (1998). Estos autores distinguen entre la metáfora propiamente tal que estructura el pensamiento o, al decir de Shotter (2001), remiten a estructuras lingüísticas que permiten un determinado tipo ya sea de acción o reflexión, de las expresiones metafóricas que corresponden a expresiones individuales basada en una determinada analogía (Daza, 2015). Por ejemplo, en la siguiente frase Los procesos defensivos modifican el registro de la información interna y externa alterando el procesamiento integrado de la información en los distintos sistemas de memoria, las expresiones "procesos defensivos", "información interna y externa", "procesamiento integrado de la información", "sistemas de memoria" serían expresiones metafóricas de la metáfora estructural "el cerebro es un computador" recurrente en la psicología cognitiva; así, el dominio de origen de estas expresiones metafóricas sería el lenguaje computacional. Luego de identificadas las metáforas con sus consiguientes expresiones metafóricas, se procedió a analizar y problematizar las metáforas que hacen alusión al ámbito de la infancia y la crianza, que es el área en la que hemos circunscrito nuestro trabajo; finalmente, se identificaron dos grandes familias de metáforas vinculadas a la relación madre e hijo y el sistema de apego. De este modo, conseguimos observar qué tipos de metáforas son usadas en el discurso científico relativo al apego, mostrando qué tipo de sistemas conceptuales organizan este discurso.

\section{CORPUS DOCUMENTAL}

Se realizó un muestreo de tipo teórico (Flick, 2015; Ruiz-Olabuénaga, 2003; Valles, 2000) de artículos, fundamentalmente de aquellos que refirieron a apego y conceptos científicos relacionados con este campo teórico (sensibilidad materna, conductas de apego, etc.). La definición operacional de producción científica chilena corresponde a todos aquellos artículos donde participa al menos, un/una científico/a chileno/a. Para ello se realizó una búsqueda en las bases de datos Web of Science, Scopus y Scielo. Los criterios de búsqueda fueron amplios y correspondieron a la presencia, en título, resumen y cuerpos de los artículos, de las palabras claves apego y attachment, representaciones mentales del apego y estilos de apego, limitados a infancia (se excluyó artículos que refirieron a apego adulto, por salirse de los márgenes teóricos establecidos anteriormente). Luego se buscaron nuevos artículos dentro del listado de referencias de cada artículo. Se consideró el período 2010-2017. Los criterios de inclusión fueron publicaciones en castellano, de cualquier naturaleza metodológica, dentro de las áreas de las ciencias sociales y la psicología. Los criterios de exclusión se formularon a nivel de idioma en que fue publicado el artículo, es decir, se excluyeron aquellos textos que no estuvieran escrito en castellano con el fin de evitar las evidentes pérdidas o transformaciones de significados relativos a la traducción de un idioma a otro, ello, bajo el supuesto de que traducciones de un idioma a otro no son simples ejercicios de traslación, sino que crean sentidos, y por tanto se pueden ver alteradas las funciones de la interpretación. También se excluyeron aquellos artículos que no presentaron una estructura acorde a las normas para artículos de investigación científica (editoriales o artículos sin resumen o palabras clave). Así el corpus quedó conformado por 19 artículos (Tabla 1).

\section{RESULTADOS}

A partir del análisis realizado, observamos que la mayoría de las metáforas identificadas en los textos científicos no aparecen de forma aislada. Su eficacia y fuerza ilocucionaria, es decir, su función dentro de un contexto lingüístico en relación con la producción de hechos científicos aumenta por funcionar en un entorno textual más amplio donde se articulan las expresiones figuradas en relaciones mutuas o en relaciones con otros elementos del texto. Así, por ejemplo, y tal como veremos, las metáforas de libro se nutren de las metáforas de animal y viceversa; o la metáfora del cuerpo como contenedor con la de homúnculo. En este contexto es que la presentación separada de las familias de metáforas asociadas a un tema (relación madre-hijo y sistema de apego) hay que considerarla solo en términos de aumentar la comprensión de los hallazgos.

\section{Relación madre-hijo}

Esta relación social se enuncia en la mayor parte de los textos mediante la expresión de la "díada" y en torno a ella se organizan varias metáforas y dominios de origen con los que se estructuran ciertos significados y representaciones de las interacciones madre e hijos/as y las prácticas de crianza.

\subsection{El cuerpo como contenedor \\ Leamos los siguientes extractos:}

"En esta línea, los estudios describen secuelas biológicas, psicológicas y sociales de la 


\section{Tabla 1}

\section{Corpus documental}

\begin{tabular}{|c|c|c|c|}
\hline Autores & Año & Título & Revista \\
\hline $\begin{array}{l}\text { Santelices, M. P. } \\
\text { y Quezada, V. }\end{array}$ & 2010 & $\begin{array}{l}\text { Apego y psicopatología materna: relación } \\
\text { con el estilo de apego del bebé al año de vida. }\end{array}$ & $\begin{array}{l}\text { Revista Latinoamericana de } \\
\text { Psicología. }\end{array}$ \\
\hline $\begin{array}{l}\text { Fresno, A., Spencer, } \\
\text { R. y Retamal, T. }\end{array}$ & 2011 & $\begin{array}{l}\text { Maltrato infantil y representaciones de apego: } \\
\text { defensas, memoria y estrategias, una revisión. }\end{array}$ & Universitas Psychologica. \\
\hline $\begin{array}{l}\text { Fresno, A. y } \\
\text { Spencer, R. }\end{array}$ & 2011 & $\begin{array}{l}\text { Efecto del Maltrato Físico en la Calidad de las } \\
\text { Representaciones de Apego Infantil en Chile: } \\
\text { Resultados Preliminares. }\end{array}$ & Terapia Psicológica. \\
\hline Lecannelier et al. & 2011 & $\begin{array}{l}\text { Apego y psicopatología: Una revisión } \\
\text { actualizada sobre modelos etiológicos } \\
\text { parentales del apego desorganizado. }\end{array}$ & Terapia Psicológica. \\
\hline Santelices, M. et al. & 2012 & $\begin{array}{l}\text { Medición de la sensibilidad del adulto con } \\
\text { niños de } 6 \text { a } 36 \text { meses de edad: construcción y } \\
\text { análisis preliminares de la escala de sensibilidad } \\
\text { del adulto, E.S.A. }\end{array}$ & Terapia Psicológica. \\
\hline $\begin{array}{l}\text { Grimalt, L. y } \\
\text { Heresi, E. }\end{array}$ & 2012 & $\begin{array}{l}\text { Estilos de apego y representaciones maternas } \\
\text { durante el embarazo. }\end{array}$ & Revista Chilena de Pediatría. \\
\hline Olhaberry, M. & 2012 & $\begin{array}{l}\text { Interacciones tempranas y género infantil en } \\
\text { familias monoparentales chilenas. }\end{array}$ & $\begin{array}{l}\text { Revista Latinoamericana de } \\
\text { Psicología. }\end{array}$ \\
\hline $\begin{array}{l}\text { Olhaberry, M. y } \\
\text { Santelices, M.P. }\end{array}$ & 2013 & $\begin{array}{l}\text { Presencia del padre y la calidad de la interacción } \\
\text { madre-hijo: un estudio comparativo en familias } \\
\text { chilenas nucleares y monoparentales. }\end{array}$ & Universitas Psychologica. \\
\hline Olhaberry, M. et al. & 2013 & $\begin{array}{l}\text { Intervenciones psicológicas perinatales en } \\
\text { depresión materna y vínculo madre-bebé: una } \\
\text { revisión sistemática. }\end{array}$ & Terapia Psicológica. \\
\hline $\begin{array}{l}\text { Muños, M., Poo, A. } \\
\text { Bustos, L. y Baeza, B. }\end{array}$ & 2014 & $\begin{array}{l}\text { Acuerdo entre tres evaluadores y un experto } \\
\text { en la detección de riesgo relacional en el } \\
\text { postparto entre la madre y su recién nacido, } \\
\text { Temuco, IX Región, Chile, } 2010 \text {. }\end{array}$ & $\begin{array}{l}\text { Revista Colombiana de } \\
\text { Obstetricia y Ginecología. }\end{array}$ \\
\hline $\begin{array}{l}\text { Muñoz, M., Poo, A., } \\
\text { Baeza, B. y Bustos, L. }\end{array}$ & 2015 & $\begin{array}{l}\text { Riesgo relacional madre-recién nacido. Estudio } \\
\text { de prevalencia y variables asociadas. }\end{array}$ & Revista Chilena de Pediatría. \\
\hline Olhaberry, M. et al. & 2015 & $\begin{array}{l}\text { Intervención grupal para reducir la } \\
\text { sintomatología depresiva y promover la } \\
\text { sensibilidad materna en embarazadas } \\
\text { chilenas. }\end{array}$ & Suma Psicológica. \\
\hline Santelices, M. et al. & 2015 & $\begin{array}{l}\text { Factores predictivos de sensibilidad } \\
\text { materna en infancia temprana. }\end{array}$ & Psicoperspectivas. \\
\hline $\begin{array}{l}\text { Santelices, M. P., } \\
\text { Besoain, C. y Escobar, J. }\end{array}$ & 2015 & $\begin{array}{l}\text { Monoparentalidad, trabajo materno y } \\
\text { desarrollo psicomotor infantil: un estudio } \\
\text { chileno en niños que asisten a salas cunas } \\
\text { en contexto de pobreza. }\end{array}$ & Universitas Psychologica. \\
\hline
\end{tabular}




\begin{tabular}{llll}
\hline \multicolumn{1}{c}{ Autores } & Año & \multicolumn{1}{c}{ Título } & \multicolumn{1}{c}{ Revista } \\
\hline $\begin{array}{l}\text { Huaquián, C., Mansilla, } \\
\text { J. y } \\
\text { Lasalle, V. }\end{array}$ & 2016 & $\begin{array}{l}\text { Apego: representaciones de educadoras de } \\
\text { párvulo en jardines infantiles en Temuco, } \\
\text { Chile. }\end{array}$ & $\begin{array}{l}\text { Revista Latinoamericana de } \\
\text { Ciencias Sociales, Niñez y } \\
\text { Juventud. }\end{array}$ \\
\hline Santelices, M. P. et al. & 2016 & $\begin{array}{l}\text { Intervenciones basadas en la mentalización } \\
\text { para padres y educadores: una revisión } \\
\text { sistemática. }\end{array}$ & Terapia Psicológica. \\
\hline $\begin{array}{l}\text { Gálvez, A. y } \\
\text { Farkas, C. }\end{array}$ & 2017 & $\begin{array}{l}\text { Relación entre mentalización y sensibilidad } \\
\text { de madres de infantes de un año de edad y } \\
\text { su efecto en su desarrollo socioemocional. }\end{array}$ & Psykhe. \\
\hline Miranda, A. et al. & 2017 & $\begin{array}{l}\text { Intervención Grupal en Embarazadas: } \\
\text { respuestas diferenciales de acuerdo al tipo } \\
\text { de depresión y patrón de apego. }\end{array}$ & Psykhe. \\
\hline Allende et al. & Apego en el postparto precoz: comparación \\
& 2017 & $\begin{array}{l}\text { entre madres de neonatos ingresados en el } \\
\text { Servicio de Obstetricia y en la Unidad de } \\
\text { Cuidados Intensivos Neonatales. }\end{array}$ & Enfermería Global. \\
\hline
\end{tabular}

Fuente: Elaboración propia.

depresión perinatal en la díada" (Olhaberry et al.., 2013, p. 250).

[...] "la confirmación de la influencia mutua al interior de la díada, la diferencia estadísticamente significativa está en el comportamiento de los niños(as) y no en el comportamiento de las madres" (Olhaberry, 2012, p. 84).

En estos dos extractos seleccionados, apreciamos que la relación madre e hijo es denominada con el sustantivo de díada y que desde nuestra perspectiva es más que una reunión de dos sujetos, es decir, su uso no se agota a un uso literal, sino que se amplía a un uso metafórico en la medida en que es acompañada en el primer extracto por la preposición en y en el segundo extracto por la preposición de. Esto da a entender que de acuerdo con el primer extracto ocurren cosas al interior de la díada o, de acuerdo con el segundo extracto, que a la díada le pueden ocurrir cosas. Por tanto, se conforma una imagen de la díada como un sustantivo que tiene un adentro y un afuera. Si seguimos a Lakoff y Johnson (1998), estas expresiones metafóricas abordan la relación madre-hijo a partir de lo que denominan la metáfora ontológica del cuerpo como un contenedor, y, que desde el punto de vista de la lingüística cognitiva podría adquirir las características de un esquema de imagen, esto es, un modelo y ordenamiento en nuestras acciones, percepciones y concepciones. El esquema de contenedor (Lakoff y Johnson 1998; Osorio, 2011) consiste en una distinción de límites entre un interior y un exterior o la distinción más básica entre adentro y afuera y que se expresa recurrentemente en los textos analizados en las lexicaciones en, dentro, de, afuera. Como todo esquema, remite a una experiencia corporal-física y en este caso al hecho de asumir el cuerpo de la madre y las relaciones madre-criatura como una relación de continente-contenido como se muestra en la común imagen del embarazo. Se evoca la idea convencional de la mujer como incompleta o vacía y que solo puede ser llenada o completada por medio de la gestación (Imaz Martínez, 2001). La díada, además, representa la idealización de la maternidad al tomar la forma de una ilimitada pasión de la madre hacia el hijo y como una relación mediata, fusionada y de completa unidad.

\subsection{El cuerpo como libro}

La segunda familia de metáforas se vincula al dominio y la metáfora del libro. Puede ser considerada una catacresis o metáfora recurrente que ha sido completamente asimilada al discurso científico (Calise, 2011) -por ejemplo, "el libro de la naturaleza"-. En los textos, se usa de forma preferente para 
hablar de los procesos de comunicación y relación entre la madre y el bebé (la díada) estableciendo una analogía entre cuerpo y libro. Esta vez, la metáfora se desplaza desde el cuerpo es un contenedor a el cuerpo es un libro y tal como señalamos anteriormente, ambos se articulan conformando esquemas de imágenes con mayor riqueza figurativa. Veamos algunos extractos:

Esto indica que cuando las madres no logran leer e interpretar adecuadamente las señales de sus hijos(as) y actuar de manera consistente para acoger sus necesidades" (Olhaberry et al., 2011, p. 77)

Otros autores plantean que el vínculo de apego puede alterarse cuando el cuidador fracasa "en leer los estados mentales o las necesidades del bebé" (Muñoz, Poo, Bustos y Baeza, 2014, p. 130).

Como se aprecia en estos ejemplos el uso de esta metáfora se caracteriza por su connotación naturalística y determinista, pues indica que este libro estaría escrito en el lenguaje de una naturaleza pre-simbólica ya que no se habla de lenguaje o palabras sino más bien de gestos, señales, estados mentales, etc. y, con ello, se trataría de leer señales-gestos, es decir, cuasisignos. Se podría definir como una metáfora de "interacción no simbólica" (Blumer, 1982) en que la madre responde directamente al acto del bebé sin interpretarlo, bloqueando los posibles conflictos de interpretación propios de cualquier acto semiótico. Así, por ejemplo, en los mismos extractos leemos algunos mandatos normativos como "no logran leer e interpretar adecuadamente" o "el cuidador fracasa en leer..." que refuerzan la figura de la "díada" como fusión y completud, sugiriendo la presencia de ideales del yo y distinciones binarias entre sujetas que leen o leen correctamente de las que no leen o leen incorrectamente.

\subsection{Animal}

De forma complementaria con la metáfora el cuerpo es un libro en esta familia de expresiones metafóricas agrupamos a aquellas cuyo dominio de origen hace referencia a la animalidad y que comparan y desplazan las relaciones madre-hijo a los modos de relación y agrupación animal y que adquieren cualidades zoomórficas. Aquí se destacan las lexicaciones de acoplamiento y nido. Por ejemplo, en un texto se establecen relaciones de correspondencia entre el hogar y la sala cuna a nidos, así como se lee en el extracto siguiente:

"El ingreso de un niño o niña a la sala cuna, debiera consistir en el tránsito armónico de un nido a otro nido" (Huaiquián, Mansilla y Lasalle, 2016, p. 1123).

Este registro animal se relaciona a otras metáforas menos recurrentes y que aparecen en forma aislada y que proyectan fenómenos naturales como inundación

\section{[...] como si estos eventos "inundaran" su estado mental (Lecannelier et al., 2011, p. 112).}

Este uso de los espacios sociales de crianza o signados como femeninos en la fórmula del nido es un tropo recurrente en el discurso psicológico -por ejemplo, el "síndrome de nido vacío"- y que remite a, por un lado, una imagen animalizada de las mujeres, las agencias femeninas y sus procesos subjetivos y, por otro, a una concepción romántica de los niños y el hogar; se transmite una sensación protectora y armónica que bloquea las asimetrías de poder y nuevamente evoca la fusión madre-hijo. Además, tras esta metáfora se asume que los niños/as y las mujeres están más próximas a la naturaleza que a la cultura, activando procesos de subalternización dentro de una lógica evolutiva en que la maternidad se repliega a un lugar al borde de la cultura.

\subsection{La familia como empresa}

La cuarta familia de expresiones metáforicas proyectan en la relación madre-hijo características del dominio empresarial en la que se identifican competencias, optimización, desempeño, eficacia, éxito, gestión, cultura del éxito, etc.; aquí la metáfora corresponde a la familia es una empresa.

"Los padres son los primeros confiados con la tarea de hacer de los hijos competentes miembros de la sociedad y las interacciones positivas de los padres con el niño serían críticas para optimizar el resultado en el desarrollo social, emocional y cognitivo" (Gálvez y Farkas, 2017, p. 4). 
La conexión entre un intenso cuidado materno y la cultura del éxito parece ser intuitivamente correcta y tiene algunos antecedentes psicoanalíticos que la apoyan (Huaiquián, Mansilla y Lasalle, 2016, p. 1123).

Como se indica en estos extractos, la crianza es una inversión a futuro en la lógica del capital humano ("hacer de los hijos competentes miembros de la sociedad") y la familia, es una empresa en su doble acepción: como tarea-actividad y unidad de organización dedicada a actividades que generan ganancias. En el primero apreciamos la incorporación de mandatos normativos -hacer de los hijos competentes miembros de la sociedad-y en el segundo extracto, otro mandato normativo en que los cuidados maternos son la clave para el logro de una formación subjetiva que es novedosa en el lenguaje psicológico respecto de la infancia; ya no se trataría de producir niños normales o buenos ciudadanos sino individuos exitosos revelando que la economía se cuela en los discursos psicológicos como una matriz de conducción de la conducta.

\subsection{Construcción}

Otra familia de expresiones metafóricas muestra las proyecciones de las interacciones madre-hijo al dominio espacial-constructivo. Como señala González de Requena (2014), la construcción es una metáfora dominante en la psicología (por ejemplo, la construcción social) y "operan como foco metafórico en tanto arrastran y connotan los sentidos de usos históricamente sedimentados" (p. 184). De especial relevancia en la investigación pertinente al apego es la metáfora de la base segura que podríamos definirla de acuerdo con Lakoff y Johnson (1998) como una metáfora conceptual (es decir, que hace referencia a conceptos) imprescindible para entender los fenómenos hablados por la teoría del apego. Analicemos los siguientes extractos en que la base segura se usa ya sea para hacer cosas o sobre la que se erigen o sostienen cosas:

[...] una incapacidad de regular el estrés de la separación y por ende de usar a la madre como una base segura de un modo coherente y organizado (Lecannelier et al. 2011, p. 109).

Es a partir de esta base segura, que desarrolla habilidades más eficaces para regular y controlar el estrés (Grimalt y Heresi, 2012, p. 243).
La eficacia para construir hechos científicos (Potter, 1996) de esta familia de expresiones metafóricas, y que creemos explica su uso predominante en la disciplina, es que transforma los conceptos abstractos de la teoría -del apego- en cosas manipulables y asequibles a la experiencia corporal inmediata y permiten explicar fenómenos formales en términos de conductas observables. En los extractos anteriores, hay una variabilidad interesante en el uso de la metáfora de base en el primero - usar a la madre como una base segura-se acerca más un símil o una comparación -mediante el adverbio como-y en el segundo - a partir de esta base segura-a una metáfora ontológica propiamente tal. Esto revela el uso ambiguo de las expresiones figuradas en la psicología que puede dar lugar a malos entendidos epistemológicos, en el sentido de no aclarar si los enunciados científicos tienen un carácter discursivo y retórico y, por tanto, son una forma entre otras de conocer la realidad o son meras descripciones en lo que podríamos llamar un realismo epistemológico. Ahora bien, si analizamos estas expresiones metáforicas en relación con otras expresiones del dominio constructivo, sugerimos que este campo de conocimiento se sitúa de forma próxima al realismo. Analicemos el siguiente extracto "La época de instalación del apego oscila según los casos" (Huaiquián, Mansilla y Lasalle, 2016, p. 1122). El verbo instalar, así como el oscilar invisten al apego de propiedades físicas y temporales que potencian la factualidad del objeto en tanto se le prepara y habilita para un descripción fáctica; esto sería un ejemplo contundente de la "construcción discursiva de los hechos".

\subsection{Música}

En menor frecuencia destacan las expresiones metafóricas que proyectan características del dominio musical por medio de las cuales se describen las relaciones afectivas entre madre-hijo, como tonalidad, sincronía, frecuencia y armonía.

[...] y la tonalidad afectiva utilizada por la madre en la interacción con su recién nacido. (Muñoz et al., 2014, p. 132)

[...] estableciendo una interacción armónica donde las competencias sensoriales e interactivas del bebé y las competencias maternales se acoplen sintónicamente [...] (Muñoz et al., 2014, p. 130) 
[...] baja frecuencia de afectos positivos y sincronía en las madres... (Olhaberry et al., 2015, p. 94).

En los extractos y al igual que en las metáforas del cuerpo como contenedor, como libro o las proyecciones metafóricas que asimilan la relación madre e hijo al dominio animal, la proyección al dominio musical revela una dimensión normativa que es muy cercana a la idea de acoplamiento y fusión propia de las metáforas naturalísticas o zoomórficas. Esta vez, lo que se revela, es la dimensión afectiva de la relación madre-hijo al modo de intensidades $\mathrm{y}$ variaciones sonoras adecuadamente acomodadas o equilibradas (armónicas). No hay que descuidar que "armonía" también hace referencia a paz y, siguiendo el esquema musical, evoca una sensación de relajación y sosiego (armonía consonante), o de tensión y vibraciones hirientes (armonía disonante o dispuesta). Acá surge la pregunta si estas expresiones metafóricas pueden ser asimiladas a la idea de "el cuerpo como partitura" y que compartiría las mismas características de la metáfora el "cuerpo como libro".

\section{El sistema de apego}

A diferencia de la dimensión anterior estudiada (relación madre-hijo) esta dimensión se constituye por un conjunto de metáforas conceptuales (Lakoff y Johnson, 1998), en tanto el punto de referencia y comparación es un concepto y no cosas o relaciones.

\subsection{Metáfora del homúnculo}

Analicemos el siguiente extracto

\begin{abstract}
"En la estrategia de desactivación el niño opta por desactivar su sistema de apego para evitar conflictos con su cuidador y el dolor ante el rechazo de sus demandas, desarrollando un patrón de apego evitativo" (Fresno, Spencer y Retamal, 2012, p. 833).
\end{abstract}

Apreciamos en este extracto la presencia de un yo que activa o desactiva voluntariamente ("opta") sus propios procesos mentales. Este error lógico en que pareciera que el sujeto y los procesos mentales están separados ha sido llamado la falacia del homúnculo, una metáfora que remite a la presencia de una especie de hombrecillo que lleva a cabo las operaciones mentales. De acuerdo con Cabré (2011), la metáfora de homúnculo es una de las más utilizadas para referirse a la mente, según esta, el humano tendría una entidad o ser interior que representa, interpreta y lee los datos que vienen desde el exterior o como en este caso, realiza cosas. En la psicología representa la imposibilidad de desprenderse del sujeto cartesiano, en que el sujeto sería dueño de una mente que es distinta al mismo sujeto.

\subsection{La mente es computador}

Las metáforas computacionales sirven para explicar el sistema de apego con relación con máquinas cibernéticas y son ampliamente utilizadas en psicología por los enfoques cognitivistas (Blanco, 1993). Se trataría de una metáfora popular -la mente es un computador- y utilizada tanto en la vida cotidiana como en los discursos científicos (Bustamante, 1993). El sistema de apego trataría de un funcionamiento cibernético que no necesita de energías externas para funcionar ni una dirección para indicar cómo hacerlo; con este tipo de descripción se hace referencia tanto a la mente del niño y la madre por separado como a la díada. En este último caso se trataría de intercambios cerrados de información, ya que tanto las instrucciones para el funcionamiento de la díada como los datos que se utilizan en su relación están ya contenidos en el interior de esta.

[...] el apego se define como una regulación diádica de la emoción (Muñoz et al., 2015, p. 27).

[...] resultado de un conjunto de pautas de conducta características, en parte programadas y controladas por el sistema nervioso central. (Allende et al.., 2017, p. 296).

Esta última expresión metafórica (programadas y controladas por el sistema nervioso central) es particularmente interesante, pues no solo conecta y asimila la mente a un computador, sino que además se aprecia un proceso de personificación del sistema nervioso reintroduciendo la metáfora del homúnculo -es decir, el sistema nervioso como un agente que programa y controla conductas-; se le atribuyen propiedades humanas de comandar o liderar adquiriendo cierta similitud con lo que Baddeley (1986) llama la metáfora del ejecutivo central o el hombre del maletín que dirige las conductas y procesos mentales. 
Es importante destacar que los textos analizados de forma recurrente muestran el uso de las metáforas del homúnculo como del computador de forma relacionada y muchas veces ambas refieren a la mente, como se aprecia en el siguiente extracto, en el que la expresión metafórica desactivación que como analizamos en la metáfora anterior se vincula al homúnculo, en el extracto siguiente se intercambia por desconexión que es más cercana a computador:

La exclusión defensiva puede manifestarse a través de una desactivación del sistema de comportamientos de apego o por una desconexión cognitiva. (Fresno, Spencer y Retamal, 2012, p. 831).

\subsection{Guerra. Apreciamos que en los extractos} siguientes las alusiones a la guerra no son menores:

Bowlby propuso que estos "asaltos al sistema de apego" generaban estrategias defensivas en el niño bajo la forma de "sistemas segregados" (procesos disociativos) (Lecannelier et al., 2011, p. 111)

Frente a situaciones de amenaza, la estrategia primaria o segura corresponde a la puesta en acción de conductas para restablecer la cercanía con la figura de apego y ser calmado emocionalmente para luego explorar el entorno inmediato (Fresno y Spencer, 2011, p. 192).

Las expresiones metafóricas de "asaltos", "estrategias defensivas", "amenaza" y "estrategia primaria", advierten acerca del uso de expresiones propias del dominio bélico para explicar el riesgo y la vulnerabilidad infantil. En ese sentido, los conceptos de la teoría del apego tienen una matriz fuertemente vinculada a un imaginario de la guerra (Calquín, 2016). Estas expresiones bélicas se relacionan semánticamente a las expresiones empresariales, pues la actividad empresarial de la familia (en su doble vertiente de actividad e inversión) se evalúa en términos de gestionar amenazas y asaltos. Con esto advertimos que el riesgo ampliamente usado en los artículos y en la psicología en general, al ser también una metáfora cuyo dominio de origen se identifica en el dominio económico puede ser considerado como una "metáfora de nivel genérico" (Choi y Bermúdez, 2006) que engloba metáforas específicas como guerra o seguridad.
Veamos el siguiente párrafo que es especialmente significativo por el uso de una amplia gama de lexicaciones metafóricas (alvéolo, fragüe, regularán) que le dan mayor fuerza ilocucionaria a la idea del apego y la relación familiar como un escudo, otra expresión metafórica asociado a la guerra:

La familia, como plantea Del Barrio, es el primer alvéolo social del niño o niña, por tanto, su papel es esencial a la hora que se fragüe la configuración de los esquemas que regularán la interacción futura del niño o niña con su entorno. Unas buenas relaciones familiares permiten una adecuada adaptación social, y se constituyen en escudo emocional para afrontar los éxitos y fracasos en la vida. (Huaiquián, Mansilla y Lasalle, 2016, p. 1123).

En este extracto, y en los que se muestran a continuación, se aprecia que el mismo ciclo vital humano se construye semánticamente como una batalla (además de una empresa e inversión) y los procesos psíquicos como procesos defensivos, una metáfora bélica ampliamente utilizada por la teoría psicoanalítica que es resemantizada con la metáfora del computador propio del campo cognitivo y con las metáforas del homúnculo y el ejecutivo central

\section{Los procesos defensivos modifican el registro de la información interna y externa alterando el procesamiento integrado de la información en los distintos sistemas de memoria (Fresno, Spencer y Retamal, 2012, p. 834).}

\section{[...] los niños desarrollarían procesos defensivos para enfrentarlas, tales como la exclusión defensiva y la segregación del sistema principal (Fresno, Spencer y Retamal, 2012, p. 830).}

\section{DISCUSIONES}

Este trabajo tuvo como objetivo descubrir el uso de un cierto número de metáforas en la producción científica chilena sobre apego, para relevar las formas discursivas en que se articulan ciencia, lenguaje y sociedad y dar cuenta, de este modo, de las comprensiones culturales implícitas en el saber experto acerca de la infancia y su cuidado. Nuestra propuesta fue indagar en el apego en tanto objeto frontera entre el conocimiento científico, la divulgación y la acción de las políticas públicas. Si bien este estudio es muy distinto al realizado por Star y Griesemer (1989), hemos logrado identificar algunas conexiones entre ciencia y no ciencia, asî 
como materialidad y retórica como elemento clave de los objetos frontera.

El estudio reveló un conjunto integrado de conceptos, categorías y concepciones de la niñez y la maternidad -y no solo adornos del lenguaje-. En ellas, logramos conocer algunos discursos normativos de la piscología que se muestran como meras descripciones de hechos, aumentando con esto los efectos de verdad de ciertos discursos psicológicos en la palestra pública y que, desde el punto de vista de las circulaciones del objeto frontera, pueden ser problemáticos. Como señalábamos en la discusión teórica, los saberes incorporan metáforas existentes en la sociedad y, asimismo, son productores de metáforas, en ese sentido, estos artículos revelan y naturalizan normas tradicionales de género que pueden servir a proyectos políticos conservadores. Así apreciamos que la infancia, la maternidad, la relación madre-hijo y la misma crianza se proyectan, por un lado, desde un dominio natural y en una relación estrictamente dual -el padre es el gran ausente en estos textos- y en que los intereses de mujeres y niños/as fuesen naturalmente los mismos o complementarios, lo que es peligroso tanto para los intereses de las mujeres como de los niños y niñas bloqueando comprensiones más complejas de las familias como una formación social repleta de tensiones y de ejercicios de exclusión.

Estas metáforas naturalísticas y zoomórficas se potencian con las metáforas bélicas, en que la relación madre-hijo se significa como un espacio natural que protegería a la infancia de los riesgos y amenazas del medio. El sistema conceptual bélico se encuentra presente en nuestra cultura económica y política -principalmente, en el ámbito de las negociaciones-desde hace mucho tiempo (Cuvardic, 2004). En la psicología, estructura las formas de aproximación a la noción de riesgo y relación. Las metáforas bélicas configuran el pensamiento, de modo que el uso de metáforas vinculadas a la luchas y el enfrentamiento del otro, o a las ansiedades por protegerse de una multiplicidad de riesgos, elaboran una versión no solo de la infancia sino de la sociedad que relegitima las tramas dominantes de la llamada sociedad de la seguridad, y en que los niños rodeados de peligro, fácilmente son despojados de las múltiples formas de agenciamiento social y psicológico que son posibles y que de alguna manera expresan los imaginarios tanatológicos respecto de la infancia que aparecen con mucha fuerza durante el siglo XX (Calquín, 2016).
Las metáforas empresariales, por otro lado, revelan la incorporación y naturalización de la ideología del capital humano y que, desde nuestra perspectiva, participa de una trama en que el modelo de empresa es una fórmula de producción de subjetividad y, la competencia, un principio de inteligibilidad. Respecto de las metáforas computacionales, estas obedecen a "metáforas muertas" (Ricoeur, 2001) inscritas en el lenguaje sedimentado y los esquemas mentales de la psicología y los psicólogos. Blanco se pregunta (1993) si es el computador es a la psicología lo que es el telescopio a la astronomía. Las metáforas computacionales adquieren fuerza pues también son condición misma de la emergencia de una comunidad científica en la psicología, y pareciera que es una garantía de una "ciencia-dura" a pesar de que conviven junto con los humúnculos y representaciones mentales. Esos modelos cibernéticos que consideran el cerebro y a sus partes como máquinas de cálculo, corren el riesgo de reposicionar un modelo mecanicista de la conducta si no se establece la distancia ontológica entre considerar el cerebro y la mente como un computador a ser un computador.

A partir de estos hallazgos, notamos que las metáforas asumen la función de comunicadores o conectores entre los múltiples universos simbólicos y mundos sociales que estos objetos habitan, facilitando y llevando a cabo traducciones entre mundos sociales heterogéneos como la economía, la guerra, la computación y la zoología, lo que revela la dimensión plástica de los objetos de conocimiento, así como su inherente relacionalidad. En ese sentido, las operaciones tropológicas de sustitución que se llevan a cabo en este campo disciplinar y que elaboran versiones autorizadas de la maternidad dan cuenta de, por un lado, los objetos de conocimiento no son entidades a la espera de ser descubiertos sino más bien son producidos por medio de tecnologías semiótica-materiales, y por otro, que el cuidado de la infancia es un campo de disputas entre universos culturales complejos en competencia a la vez en insertos en procesos de hibridación. También, que en la producción de dispositivos textuales y de saber -artículos científicos-implosionan discursos y materialidad, ciencia y no ciencia y las metáforas por medio de un trabajo tropológico invisible, permiten simplificar la complejidad de estos objetos. El uso de las metáforas en la ciencia psicológica sugiere la idea del conocimiento como producto y proceso a la vez, en que los procesos textuales 
de producción tropológica llevados a cabo por los científicos no son una distorsión semántica, ni un residuo o simplemente un medio de difusión de resultados, sino su misma materialidad y condición de posibilidad.

La noción de Barad (1998 en Neely, 2020) de lógicas materiales entremezcladas (entangled material agencies) nos sirven para mostrar la función de la metáfora en el conocimiento científico en donde el sujeto hablante no es exterior al mundo y no le preexiste, tal como apuntaba Haraway (2011) con la noción de conocimientos situados como alternativa crítica a la "visión desde todos lugares y desde ninguna parte". En ese sentido, las metáforas no representan un actor o una visión de mundo - pues no hay mundo antes de la división entre visible/invisible- sino que se configuran como un actor que hacen y deshacen cosas y, siguiendo a Trompette y Vinck (2009), adquieren las propiedades de infraestructuras relacionales invisibles que no son específicas a uno u otro mundo social. Como indican Granjou y Mauz (2009), no es el objeto frontera aislado el que permite la coordinación entre los participantes de la empresa colectiva -al modo de un objeto preformado-; son estas infraestructuras invisibles que equipan al objeto frontera para llevar a cabo trayectorias entre comunidades y contextos heterogéneos al mismo tiempo ser transformados por ellas al tiempo que mantener cierta consistencia ontológica.

Para terminar, es necesario destacar los límites de este trabajo. El análisis arrojó una cantidad inusitada de metáforas, que por motivos de espacio no fueron presentadas. Por tanto, las presentadas acá no agotan el campo discursivo ni la red de relaciones en los conocimientos autorizados respecto de los vínculos y la crianza. 


\section{REFERENCIAS}

Amar, J. (2014). La política es un juego: un análisis de la metáfora política en la prensa española. European Scientific Journal, 10 (4), 233-249.

Allende, L., González; L. Pérez, F., y Fernández, D. (2017). Apego en el postparto precoz: comparación entre madres de neonatos ingresados en el Servicio de Obstetricia y en la Unidad de Cuidados Intensivos Neonatales. Enfermería Global, 45, 295-308.

Atkinson, P. y Coffey, A. (2005). Encontrar el sentido a los datos cualitativos. Alicante: Publicacions Universitat d`Alacant.

Baddeley, A. D. (1986). Working Memory. Oxford: Churchill Livingstone.

Barudy, J. y Dantangan, M. (2005). Los buenos tratos a la infancia. Parentalidad, apego y resiliencia. Buenos Aires: Gedisa.

Blanco, C. (1993). El telescopio de la psicología. Acerca de la metáfora computacional en psicología cognitiva. Psicothema, 5 (2), 303-310

Blumer, (1982). El Interaccionismo simbólico. Perspectiva y método. Barcelona: Hora.

Berri, M. y Bregant, L. (2015). Identificación de metonimias y metáforas: cuestiones metodológicas. Lenguaje, 43 (2), 219-245.

Bowlby, J. (1969/2012). El apego y la pérdida. T. 1 El apego. Buenos Aires: Paidós.

Bowlby, J. (1972/2009). El apego y la pérdida. T 2. La separación. Buenos Aires: Paidós.

Bustamante, J. (1993). La metáfora computacional: el mito de la replicación artificial del hombre y el orden social (Una crítica desde la perspectiva de los estudios de ciencia, tecnología y sociedad). Cuadernos de Trabajo social, 6, 33-59.

Cabré, T (2011). Terminología y normalización lingüística [en línea]. Disponible en: https://www.ehu.eus/ documents/2430735/2877801/cabret.pdf

Cabrera P., Larraín, A., Moretti, M; Arteaga, M., Energici, A. (2010). La formación en psicología desde una perspectiva de competencias. Una contribución para el mejoramiento de la formación universitaria en Chile. Calidad en la educación, $33,183-221$

Calise, S. (2011). La clonación y sus metáforas. Sobre cómo el sistema jurídico argentino comprende la clonación humana. Discurso y sociedad, 5 (2), 259-298.

Callon, M. (1986). Algunos elementos para una sociología de la traducción: la domesticación de las vieras y los pescadores de la bahía de St. Brieuc. En Iranzo, J., Blanco, R., González de la Fe, T., Torres, C. y Cotillo, A. (comp.). (1995). Sociología de la ciencia y la tecnología. Madrid: CSIC.

Callon, M. (1998). El proceso de construcción de la sociedad. El estudio de la tecnología como herramienta para el análisis sociológico. En Domenech, M. y Tirado, J. (comps.) Sociología simétrica. Ensayos sobre ciencia, tecnología y sociedad (pp. 143170). Barcelona: Gedisa.

Callon, M. y Law, J. (1998) De los intereses y su transformación. Enrolamiento y contraenrolamiento. En Domenech, M y Tirado, F. (comps.) Sociología simétrica. Ensayos sobre ciencia, tecnología y sociedad (pp. 51-62). Barcelona: Gedisa.
Calquín, C. (2016). Apego e interfaces entre amor de madre, máquinas de cine y cibernéticas. Athenea Digital: Revista de pensamiento e investigación social, 16(1), 305-325.

Castro, G. (2015). Paráfrasis y sentido común en el discurso de divulgación infantil. Ponencia En Pérez, Sara I. Actas del VI Coloquio de Investigadores en Estudios del Discurso y III Jornadas Internacionales sobre Discurso e Interdisciplina / Sara I. Pérez; Ana M. Aymá. Bernal: Universidad Nacional de Quilmes, 2015.

Crespo, E. (2003). El construccionismo y la cognición social: metáforas de la mente. Política y Sociedad, 40 (1), 15-26.

Chile Crece Contigo (2008). Manual para el apoyo y seguimiento del desarrollo psicosocial de los niños y niñas de 0 a 6 años. Documento de trabajo: Santiago de Chile.

Choi, D. y Bermúdez, N. (2006). Metáfora y metonimia en el lenguaje visual. En Di Stefano, Metáforas en uso. Buenos Aires: Biblos.

Cuvardic, D. (2004) La Metáfora de guerra en el discurso político. Revista Reflexiones 83 (2), 61-72.

Daza, C. E. (2015). La metáfora cromática en el cine de infancia: una revisión a una década largometrajes sobre niñez. Infancias e Imágenes, 14 (1), 59-76.

Danziger, K. (1990). Generative metaphor and the history of psychological discourse. En D. E. Leary (Ed.). Metaphors in the history of psychology (pp. 331-357). New York: Cambridge University Press.

Domenech, M. y Tirado, J. Claves para un lectura de textos simétricos. En Domenech, M. y Tirado, J. [comps] (1998). Sociología simétrica. Ensayos sobre ciencia, tecnología y sociedad. Barcelona: Gedisa.

Flick, U. (2015). El Diseño de investigación cualitativa. Madrid: Morata.

Fresno, A; Spencer, R; Leiva, M; Gallardo. I. (2011). Ingreso familiar y variables psicológicas asociadas a la pobreza como predictores de la calidad de la representación del apego en niños preescolares en Chile. Revista Latinoamericana de Psicología de la Salud y Social, 2 (2), 176-192.

Fresno, A., Spencer, R. y Retamal, T. (2012). Maltrato infantil y representaciones de apego: defensas, memoria y estrategias, una revisión. Universitas Psychologica. 11 (3), 829-838.

Fresno, A. y Spencer, R. (2011). Efecto del Maltrato Físico en la Calidad de las Representaciones de Apego Infantil en Chile: Resultados Preliminares. Terapia psicológica, 29 (2), 191-196.

Gálvez, A. y Farkas, C. (2017). Relación entre mentalización y sensibilidad de madres de infantes de un año de edad y su efecto en su desarrollo socioemocional. Psykhe, 26 (1), 1-14.

González, J. (2014). Procesos y construcciones: Un análisis de contenido de las metáforas en dos revistas de Psicología, Psicoperspectivas, 13 (2), 174-185.

Goodman, N. (1990). Maneras de hacer mundos. Madrid: Visor.

Granjou C. y Mauz I. (2009). Quand l'identité de l'objet-frontière se construit chemin faisant. Le cas de l'estimation de l'effectif de la population de loups en France. Revue d'Anthropologie des Connaissances, 3 (1), 29-49. 
Grimalt, L. y Heresi, E. (2012). Estilos de apego y representaciones maternas durante el embarazo. Revista chilena de pediatría, 83 (3), 239-246.

Haraway, D. (2011). Testigo Modesto@; Segundo Milenio. Hombre hembra conoce Oncoraton. Feminismo y tecnociencia. Barcelona: Editorial UOC.

Huaquián, C., Mansilla, J. y Lasalle, V. (2016). Apego: representaciones de educadoras de educadoras de párvulo en jardines infantiles en Temuco, Chile. Revista Latinoamericana de ciencias sociales, niñez y juventud. 14 (2), 1119-1129.

Hulbert, C., Jennings, T., Jackson, H., Chanen, A. (2011). Attachment style and schema as predictors of social functioning in youth with borderline features. Personality and Mental Health, 5, 209-221.

Ibáñez, T. (2011). El cómo y el por qué de la psicología social. En Ibáñez, T. [Coord.] Introducción a la psicología social. Barcelona: UOC.

Imaz Martínez, E. (2001). Mujeres gestantes, madres en gestación. Metáforas de un cuerpo fronterizo. Política y Sociedad, $36,97-111$.

Íñiguez, L. (2006). EL análisis de discurso en las ciencias sociales: variedades, tradiciones y práctica. En Íñiguez-Rueda, L. (ed.). Análisis del discurso. Manual para las ciencias sociales. Barcelona: Ediciones UCO.

Jordan, B. (1992). Authoritative knowledge and its construction. Ponencia Annual Meetings of the American Anthropological Association, San Francisco CA.

Lakoff, G. y Johnson, M. (1998). Metáforas de la vida cotidiana. Madrid: Cátedra.

Latour, B. (2008). Reensamblar lo social. Introducción a la Teoría del Actor Red. Buenos Aires: Manantial.

Leary, D. (1990). Metaphors in the history of Psychology. New York: Cambridge: University Press.

Lecalennier, F. (2006). Apego e Intersubjetividad. Tomo 2. Santiago: LOM Ediciones.

Lecannelier, F., Ascanio, L., Flores, F., y Hoffman, M. (2011). Apego y psicopatología: Una revisión actualizada sobre modelos etiológicos parentales del apego desorganizado. Terapia psicológica, 29 (19), 107-116.

Lorenzini, N. y Fonagy, P. (2014) Apego y trastornos de la personalidad: breve revisión. [en linea]https://www.researchgate. net/publication/261913631_Apego_y_trastornos_de_la_personalidad_breve_revision

Martínez, A. (2014). Cambiar metáforas en la psicología social de la acción pública: de intervenir a involucrarse. Athenea Digital, 14 (1) 3-28.

Meza, P. (2010). Uso de metáforas cognitivas en textos periodísticos pertenecientes al ámbito de la salud. Logos, 20 (1), 81-107.

Millán, J. y Narotzky, S. (1998). Introducción de Metáforas de la vida cotidiana. Madrid: Cátedra.

Miranda, A., Olhaberry, M. Morales-Reyes, I. (2017). Intervención Grupal en Embarazadas: respuestas diferenciales de acuerdo al tipo de depresión y patrón de apego. Psykhe 26 (1) 1-17.

Muñoz, M., Poo, A. Bustos, L. y Baeza, B. (2014) Acuerdo entre tres evaluadores y un experto en la detección de riesgo relacional en el postparto entre la madre y su recién nacido, Temuco,
IX región, Chile, 2010. Revista colombiana de Obstetricia y ginecología. 65 (2) 129-138.

Muñoz, M., Poo, A., Baeza, B. y Bustos, L. (2015). Riesgo relacional madre-recién nacido. Estudio de prevalencia y variables asociadas. Revista chilena de pediatría, 86 (1), 25-31.

Neely, A. (2020). Entangled agencies: Rethinking causality and health in political-ecology. Environment and Planning, E: Nature and Space.

Olhaberry, M. (2012). Interacciones tempranas y género infantil en familias monoparentales chilenas. Revista Latinoamericana de psicología, 44 (2), 75-86.

Olhaberry, M., Escobar, M., San Cristóbal, P., Santelices, M. Farkas, C. Rojas, G. y Martínez, V. (2013). Intervenciones psicológicas perinatales en depresión materna y vínculo madre-bebé: una revisión sistemática. Terapia psicológica. 31 (2) 249-261.

Olhaberry, M., Escobar, M., Mena, C. Santelices, M., MoralesReyes, I. Rojas, G. y Martínez, V. (2015). Intervención grupal para reducir la sintomatología depresiva y promover la sensibilidad materna en embarazadas chilenas. Suma Psicológica 22, 93-105.

Orlandi, E. (2012). Análisis de discurso. Principios y procedimientos. Santiago: LOM.

Osorio, J. (2011). Patudos, entradores y metidos: metáfora, esquema de imagen e idealización en ejemplos del léxico popular chileno de la conducta social. Relaciones, 32 (128), 97-115.

Pragglejaz Group (2007). MIP: A Method for Identifying Metaphorically Used Words. Discourse, Metaphor and Symbol, 22 (1) 1, 1-39.

Potter, J. (1996). La representación social de la realidad. Buenos Aires: Paidós.

Ramos, C. (2016). La producción de la pobreza como objeto de gobierno. Santiago: UAH.

Ricoeur, P. (2001). La Metáfora viva. Madrid: Trotta.

Rodríguez, L. (2013). Objetos subordinantes: la tecnología epistémica para producir centros y periferias. Revista Mexicana de Sociología, 75 (1), 7-28.

Ruiz-Olabuénaga, J. (2003). Metodología de la investigación cualitativa. Bilbao: Deusto.

Saavedra, C. (2015). ¿Qué es Chile Crece Contigo? Santiago: Gobierno de Chile, Ministerio de Desarrollo Social.

Santelices, M. P. y Quezada, V. (2010) Apego y psicopatología materna: relación con el estilo de apego del bebé al año de vida. Revista latinoamericana de psicología, 42 (1), 53-61.

Santelices, M., Carvacho, C., Farkas, C., León, F., Galleguillos, F., Himell, E. (2012). Medición de la sensibilidad del adulto con niños de 6 a 36 meses de edad: construcción y análisis preliminares de la escala de sensibilidad del adulto, E.S.A. Terapia psicológica, 30 (3), 19-29.

Santelices, M., Farkas, C. Montoya, M., Galleguillos, F., Carvacho, C. Fernández, A., Morales, L. Taboada, C. y Himmel, E. (2015), Factores predictivos de sensibilidad materna en infancia temprana. Psicoperspectivas, 14 (1), 66-76.

Santelices, M., Besoain, C., y Escobar, M. (2015). Monoparentalidad, trabajo materno y desarrollo psicomotor infantil: un estudio chileno en niños que asisten a salas cuna en contexto de pobreza. Universitas Psychologica, 14 (2), 675-684. 
Santelices, M., Zapata, J., Fischersworring, M. Pérez, F. Mata, C. Barco, B. Olhaberry, M., Farkas, C. (2016). Intervenciones basadas en la mentalización para padres y educadores: una revisión sistemática. Terapia psicológica, 34 (1) 71-80.

Star, S. L., y Griesemer. J. (1989). Institutional ecology, 'Translations', and Boundary objects: Amateurs and professionals on Berkeley's museum of vertebrate zoology. Social Studies of Science, 19, 387-420.

Shotter, J. (2001). Realidades conversacionales. La construcción de la vida a través del lenguaje. Buenos Aires: Amorrortu.

Teo, T. (2008). From speculation to epistemological violence. A critical-hermeneutic reconstruction. Theory y Psychology, 18, (1), 47-67.
Trompette, P y Vinck, D. (2009). Regreso sobre la noción de objeto frontera, Revue d'anthropologie des connaissances, 3, 14-26.

Valles, M. (2000). Técnicas cualitativas de investigación social. Madrid: Síntesis.

Vergara, A., Peña, M., Chávez, P. y Vergara, E. (2015). Los niños como sujetos sociales: El aporte de los Nuevos Estudios Sociales de la infancia y el Análisis Crítico del Discurso. Psicoperspectivas, 14 (1), 55-65.

Wodak, R., y Ferreiro, J. (2013). Análisis crítico del discurso desde el enfoque histórico: La construcción de identidad(es) latinoamericanas en la Misión de ONU en Haití (2004-2005). En Canales, M. (Coord.) Escucha de la escucha: Análisis e interpretación en la investigación cualitativa (pp. 189-230). Santiago: LOM. 